\title{
Biochar Media Addition Impacts Apple Rootstock Growth and Nutrition
}

\author{
Tom A. Street \\ School of Agricultural Science, University of Tasmania, Private Bag 54 \\ Hobart, Australia 7001
}

Richard B. Doyle and Dugald C. Close ${ }^{1}$

School of Agricultural Science, University of Tasmania, Private Bag 54 Hobart, Australia 7001; and the Perennial Horticulture Centre, Tasmanian Institute of Agriculture, University of Tasmania, Private Bag 98, Hobart, Australia 7001

Additional index words. fertilization, nutrient deficiency, pyrolysis, soil amendment

\begin{abstract}
The effects of biochar soil amendment on perennial plant nutrition and growth are poorly understood. We investigated the effects of a green waste biochar on apple rootstock (Malus domestica var. M26) nutrition and growth in a series of pot trials. Apple rootstocks were grown for 5 months in both soil and sand media, with and without biochar, under a range of fertilization, $\mathrm{pH}$, and soil biological regimes. Plant biomass and leaf nutrient concentration of apple rootstocks and substrate-induced respiration (SIR) of the soil were measured. Addition of biochar was associated with significant increases in leaf concentrations of calcium (Ca), boron (B), and sulfur (S) for apple rootstocks grown in sand. Increased uptake of $S$ has not previously been reported and may be the result of the relatively high $S$ content of the biochar used in this trial that resulted from the low temperature used to pyrolize the biomass. Plant dry mass significantly increased by between $75 \%$ and $220 \%$ where sand was amended with biochar for every fertilization treatment. Small, but statistically significant, increases in soil $\mathrm{pH}$, from $\mathrm{pHc}\left(\mathrm{CaCl}_{2}\right.$ extraction) 4.7 to 4.9, were found after the addition of biochar but no significant effect on soil SIR was detected. Our results indicate that biochar has positive effects on apple rootstock nutrition and growth in a sand but not in a sandy loam soil.
\end{abstract}

Biochar may be an effective management tool for increasing carbon (C) in orchard soils. Biochar is a charcoal-type material manufactured specifically for use as a soil amendment in agriculture. Biochar is created by charring organic matter by heating it under reduced oxygen conditions (pyrolysis) (Sohi et al., 2010). Interest in biochar has recently increased as a result of a number of factors: the cogeneration of $\mathrm{C}$-neutral

Received for publication 13 May 2014. Accepted for publication 7 July 2014.

This work was funded by the TIA Perennial Horticulture Centre and the (Australian) National Apple and Pear Orchard Productivity Program (PIPS). PIPS was funded through Horticulture Australia Limited using the apple and pear industry levy, voluntary contributions from the Plant and Food Research Institute, New Zealand, and matched funds from the Australian government. Biochar was kindly donated by Pacific Pyrolysis, Somersby, NSW. Rootstocks and soil were kindly donated by Tahune Fields Nursery, Lucaston, Tasmania. Soil, biochar, and leaf nutrient analysis was conducted by CSBP soil and plants laboratory, Bibra Lake, WA. Expertise and technical support was kindly provided by Sally Bound, Phil Andrews, Gordon Brown, Sophie Folder, Marcus Hardie, Mark Hovendon, Jorge Martins, Robert Menary, Garth Oliver, Yui Osanai, David Ratkowsky, and Marcus Smith. Sally Bound and Caroline Claye kindly reviewed an earlier version of this manuscript.

${ }^{1}$ To whom reprint requests should be addressed; e-mail Dugald.Close@utas.edu.au. electricity and biofuels from its manufacture, its $\mathrm{C}$ sequestration value, and possible soil fertility benefits (for a review, see Sohi et al., 2010). Charcoal is similar to humic substances and has rarely been differentiated from uncharred organic matter in past studies as a result of the difficulty of separating the two fractions (Chatterjee et al., 2009; Wagai et al., 2009). Hence, charcoal may contribute to benefits attributed to uncharred organic matter.

Uncharred organic matter is broken down by microbes in soil, requiring continual input to maintain soil levels. The replacement of $\mathrm{C}$ is rarely achieved in soils of large-scale conventionally managed orchards because the management costs of maintaining understory vegetation or applying mulches are generally considered to be uneconomically high. In contrast, biochar is highly resistant to microbial breakdown and has a residence time in soil of the order of 1000 years (Kuzyakov et al., 2009). Therefore, an orchardist may only need to invest in applying biochar once because the majority of biochar incorporated into the soil remains for many years. This long residence time in the soil potentially makes it an economically viable alternative to understory vegetation and mulching for increasing orchard soil $\mathrm{C}$ levels. Also, in the short term, plant-available nutrients contained within the biochar can provide fertilization benefits (Chan and $\mathrm{Xu}$, 2009), particularly low-temperature-derived biochars (less than $550{ }^{\circ} \mathrm{C}$ ) that favor the retention of $\mathrm{C}$, nitrogen $(\mathrm{N})$, potassium $(\mathrm{K})$, and $\mathrm{S}$ and tend to retain the structure of the feedstock (Keiluweit and Kleber, 2009; see Joseph et al., 2010, for a review of the reactions of biochar in soil). However, published research on the effects of biochar on trees is so far limited to a single-pot trial on the effect of activated $\mathrm{C}$ on growth, nutrition, and mycorrihzal infection rates of peach trees (Rutto and Mizutani, 2006).

Addition of biochar to the soil in some circumstances improved plant nutrition and growth of model crops such as radish and beans (Chan et al., 2007, 2008; Rondon et al., 2007). Negative effects have been reported but appear to be minor. For example, Chan et al. (2007) found a small growth decrease resulting from biochar application in unfertilized soil but found substantial growth responses to biochar with fertilizer application. The greatest benefits of biochar soil applications have been on nutrient-poor, acidic soils with low $\mathrm{C}$ and cation exchange capacity levels (CEC) (Chan et al., 2007; Kimetu et al., 2008; Rondon et al., 2007).

A wide range of mechanisms for the beneficial effects of biochar on plant growth has been suggested including: nutrient supply, increasing the $\mathrm{pH}$ of acid soils, improved soil physical attributes, reduced leaching of plant nutrients, promotion of beneficial microbes, and sorption of organic chelates (Chan et al., 2007; Deluca et al., 2009; Lehmann et al., 2003; Rondon et al., 2007). All these mechanisms may play an important role in determining the effects of biochar on plant growth and nutrition. However, these mechanisms are little understood. As a consequence, prediction of how biochar type, biochar level of application, soil, crop, and climate will interrelate to enhance crop growth is not possible at this stage. This study used apple rootstocks as a model perennial plant to assess the growth response to various root medium types and soil moisture and nutrient conditions at different biochar application rates. It was hypothesized that: 1) in acidic soil, biochar can increase apple rootstock growth through increasing soil $\mathrm{pH}$; 2) biochar can improve apple rootstock growth through increasing soil microbial biomass and hence increase nutrient mineralization and availability; and 3) biochar can increase apple rootstock growth in combination with fertilization compared with fertilization alone.

\section{Materials and Methods}

Glasshouse pot trials were conducted using M26 apple rootstocks at the University of Tasmania, Hobart, Tasmania, Australia (lat. $42^{\circ} 52^{\prime} \mathrm{S}$; long. $147^{\circ} 19^{\prime} \mathrm{E}$ ). Rootstocks were grown for 5 months (15 Oct. 2009 to 8 Mar. 2010) in soil and sand media, with and without biochar, under a range of irrigation, fertilization, and biological treatments. Glass house temperature ranged between 18 and $26^{\circ} \mathrm{C}$. 


\section{Soil and biochar treatments.}

1. Impacts of biochar on soil $\mathrm{pH}$ - soil with 0 or $50 \mathrm{~g} \cdot \mathrm{m}^{-2}$ biochar was used, with or without lime incorporated. $\mathrm{N}$ fertilizer was applied to these treatments.

2. Impacts of autoclaving on biological activity-soil with 0 or $50 \mathrm{~g} \cdot \mathrm{m}^{-2}$ biochar was used, with soil unamended, or autoclaved. No fertilizer was applied to these treatments.

3. Fertilization effects of biochar-sand with 0 or $50 \mathrm{~g} \cdot \mathrm{m}^{-2}$ biochar was used, with three fertilization treatments: 1) all essential plant nutrients except phosphorus (P), K, and $\mathrm{Ca}(-\mathrm{PKCa}$ Fert); 2) N, P, K, and $\mathrm{Ca}(+\mathrm{NPKCa}$ Fert); and 3) all essential plant nutrients (Total Fert); and

4. Effects of biochar application ratesoil with $0,10,20$ and $50 \mathrm{~g} \cdot \mathrm{m}^{-2}$ biochar was used. No fertilizer (No Fert), N fertilizer (N Fert), or a total fertilizer (Total Fert) was applied.

Soil and sand media. A washed river sand with particle size analysis of greater than $2 \mathrm{~mm}-29.4 \%, 1$ to $2 \mathrm{~mm}-29.7 \%, 355 \mu \mathrm{m}$ to $1 \mathrm{~mm}-29.0 \%, 250$ to $355 \mu \mathrm{m}-4.5 \%, 125$ to $250 \mu \mathrm{m}-4.9 \%, 90$ to $125 \mu \mathrm{m}-0.9 \%, 63$ to $90 \mu \mathrm{m}-0.6 \%$, and less than $63 \mu \mathrm{m}-1.0 \%$ was used. Particle size was determined by dry sieving (McIntyre and Loveday, 1974).

The soil used was a sandy loam, $90 \%$ sand (greater than $20 \mu \mathrm{m}$ ), $2.5 \%$ silt ( 2 to $20 \mu \mathrm{m}$ ), and $7.5 \%$ clay (less than $2 \mu \mathrm{m}$ ). Analysis of sand, silt, and clay content was determined on dispersed samples using the hydrometer method (McIntyre and Loveday, 1974). Soil was taken from 0 - to $30-\mathrm{cm}$ depth from a recently ploughed field at Tahune Fields Nursery. The field had been used the previous season for raising apricot trees; however, tree growth had been very poor. The field had been previously treated with $\mathrm{N}, \mathrm{P}$, and $\mathrm{K}$ fertilizer and lime.

Introduction of apple replant disease with the soil could be excluded because apples had never been grown on the studied soil.

Rootstocks. A total of 400 M26 apple rootstocks of $\approx 8 \mathrm{~mm}$ collar diameter were sourced from Tahune Fields Nursery, Lucaston, Tasmania. From these, the 200 most homogeneous in size and healthy appearance were selected. The roots on the stocks were pruned to roughly $1 \mathrm{~cm}$ in length and stems were cut to $35 \mathrm{~cm}$ total length.

Biochar. Biochar was produced from green waste feedstock using continuous slow pyrolysis at $350{ }^{\circ} \mathrm{C}$ with a PyroChar 4000 by Pacific Pyrolysis Pty, Somersby, New South Wales $(<$ http://www.pacificpyrolysis.com $>)$. The biochar had been produced within the previous year and had been sealed in a plastic container since production. The biochar was weighed $\approx 12$ months after being produced. The particle size analysis of the biochar was: greater than $2 \mathrm{~mm}=23.0 \%, 1$ to $2 \mathrm{~mm}=22.3 \%, 355 \mu \mathrm{m}$ to $1 \mathrm{~mm}=22.7 \%, 250$ to $355 \mu \mathrm{m}=9.7 \%, 125$ to $250 \mu \mathrm{m}=8.8 \%, 90$ to $125 \mu \mathrm{m}=8.0 \%, 63$ to 90 $\mu \mathrm{m}=4.6 \%$, and less than $63 \mu \mathrm{m}=0.9 \%$.

Preparation of root medium. Treatment media were mixed for 2 min using a cement mixer to incorporate additives. Perlite [from Exfoliators Australia, Dandenong Victoria, Australia; $\mathrm{pH} 7.5$ in a $10 \%$ (by volume) slurry] was added to all treatments at $20 \%$ by volume to improve drainage. Perlite was incorporated into all treatments for only the final $15 \mathrm{~s}$ of mixing to avoid compaction of the material. Perlite introduces significantly less plant nutrients than vermiculite [particularly ammonium, nitrate, phosphate, aluminum (Al), $\mathrm{Ca}, \mathrm{K}$, magnesium $(\mathrm{Mg})$, manganese, and sodium $(\mathrm{Na})$ ] with effective CEC of only 0.40 compared with 46.3 $\mathrm{cmol}_{\mathrm{c}} \cdot \mathrm{kg}^{-1}$ in vermiculite (Dalling et al., 2013). In relevant treatments, biochar, micronutrients, and lime were also added. The application rate of lime (from Mitchell Building Supplies, Richmond, Victoria, Australia; calcium carbonate $80 \%$, magnesium carbonate $9 \%, \mathrm{pH}$ of 13 ) needed to achieve $\mathrm{pH} 6.5$ was estimated through a pilot trial. Lime was incorporated into a test sample of soil at three application rates. The soil was left for $48 \mathrm{~h}$ and $\mathrm{pH}$ remeasured. From this, the rate expected to raise the $\mathrm{pH}$ of soil from the original $\mathrm{pHc}\left(\mathrm{CaCl}_{2}\right.$ extracted $)$ of 4.9 to 6.5 was calculated. However, the estimated rate resulted in soil $\mathrm{pH}$ of 7.0, overshooting the target of 6.5. Soil was autoclaved before mixing at $121{ }^{\circ} \mathrm{C}$ and $220 \mathrm{kPa}$ for $30 \mathrm{~min}$. Each $20-\mathrm{cm}$ diameter, $19-\mathrm{cm}$ high pot received 3.6 L of mixed potting media.

Fertilization. Micronutrients incorporated into the root media at the beginning of the trial for relevant treatments were supplied as Osmocote Micromax fertilizer (Everris Australia Pty Ltd, Bella Vista, Australia) applied at $0.4 \mathrm{~kg} \cdot \mathrm{m}^{-3}$ and $\mathrm{FeSO}_{4}$ applied at $1.0 \mathrm{~kg} \cdot \mathrm{m}^{-3}$. Micromax composition was: $\mathrm{Ca} 6 \%, \mathrm{Mg}$ $3.0 \%$, B $0.10 \%$, copper $(\mathrm{Cu}) 1.0 \%$, iron $(\mathrm{Fe})$ $17.0 \%$, Mn $2.5 \%$, molybdenum $0.05 \%$, and zinc (Zn) $1.0 \%$. All nutrients in Micromax are in water-soluble form.

After $53 \mathrm{~d}$ (and $88 \%$ of rootstocks had broken dormancy), weekly macronutrient fertilization began. The fertilizer was based on modified Hoagland's solution (Hoagland and Arnon, 1950). Amounts of weekly nutrient application for each treatment are in Table 1. Nutrients were diluted in $130 \mathrm{~mL}$ of water.

Plant, soil, and biochar measurements. At the end of the trial (144 d after planting), a range of data and images was collected. Plants were photographed individually. Plant leaves, branches, and roots were dried at $65{ }^{\circ} \mathrm{C}$ until a constant weight was reached and then weighed individually. The original rootstock stem was excluded from analysis because stems grew little during the trial and final weight would have been highly confounded by initial weight, hence giving little information about treatment effects. For the "No Fert" soil treatments, effect of biochar on soil microbial biomass was estimated using SIR as an indicator of microbial biomass, according to the methodology of Anderson and Domsch (1978). Soil and biochar were analyzed for available nutrient concentrations, $\mathrm{pH}$, and total C levels (Table 2). Soil pH (pHc) was measured with a $1: 5$ soil to $0.01 \mathrm{M} \mathrm{CaCl}_{2}$

Table 1. Weekly macronutrient application per plant (mg/element).

\begin{tabular}{lcccccc}
\hline & $\mathrm{N}$ & $\mathrm{P}$ & $\mathrm{K}$ & $\mathrm{Ca}$ & $\mathrm{S}$ & $\mathrm{Mg}$ \\
\hline $\begin{array}{l}\text { Total }-\mathrm{PKCa} \\
(\mathrm{Mg} \mathrm{SO}\end{array} \mathrm{H}_{2} \mathrm{O}$ and $\left.\mathrm{NaNO}_{3}\right)$ & 28.4 & & & & 8.8 & 6.6 \\
$\begin{array}{l}\mathrm{NPKCa} \mathrm{Fert} \\
\left(\mathrm{CaNO}_{3} \cdot 4 \mathrm{H}_{2} \mathrm{O}, \mathrm{KNO}_{3} \text {, and } \mathrm{KH}_{2} \mathrm{PO}_{4}\right)\end{array}$ & 28.8 & 4.2 & 31.9 & 27.0 & & \\
$\begin{array}{l}\text { Total Fert } \\
\left(\mathrm{CaNO}_{3} \cdot 4 \mathrm{H}_{2} \mathrm{O}, \mathrm{KNO}_{3}, \mathrm{MgSO}_{4} \cdot 7 \mathrm{H}_{2} \mathrm{O} \text {, and } \mathrm{KH}_{2} \mathrm{PO}_{4}\right)\end{array}$ & 28.8 & 4.2 & 31.9 & 27.0 & 8.7 & 6.6
\end{tabular}

$\mathrm{N}=$ nitrogen; $\mathrm{P}=$ phosphorus; $\mathrm{K}$ = potassium; $\mathrm{Ca}=$ calcium; $\mathrm{S}=$ sulfur; $\mathrm{Mg}=$ magnesium.

Table 2. Nutrient content, total carbon content, and $\mathrm{pH}$ of soil and biochar used in trial.

\begin{tabular}{|c|c|c|c|c|c|c|c|c|c|c|}
\hline & \multirow[b]{2}{*}{$\mathrm{CaCl}_{2}$} & \multirow{2}{*}{$\frac{\text { Total }}{\mathrm{C}}$} & \multicolumn{2}{|c|}{ Total } & \multicolumn{2}{|c|}{ Colwell } & \multicolumn{4}{|c|}{ DTPA } \\
\hline & & & $\mathrm{NH}_{4}{ }^{+}$ & $\overline{\mathrm{NO}_{3}{ }^{-}}$ & $\mathrm{P}$ & $\mathrm{K}$ & $\mathrm{Cu}$ & $\mathrm{Fe}$ & $\mathrm{Mn}$ & $\overline{\mathrm{Zn}}$ \\
\hline & $\mathrm{pH}$ & $(\%)$ & \multicolumn{2}{|c|}{$\left(\mathrm{mg} \cdot \mathrm{kg}^{-1}\right)$} & \multicolumn{2}{|c|}{$\left(\mathrm{mg} \cdot \mathrm{kg}^{-1}\right)$} & \multicolumn{4}{|c|}{$\left(\mathrm{mg} \cdot \mathrm{kg}^{-1}\right)$} \\
\hline Soil & 4.90 & 2.7 & 10 & 4 & 67 & 166 & 0.99 & 243 & 20.1 & 2.5 \\
\hline Biochar & 6.40 & 41.0 & 3 & 1 & 234 & 112 & 1.35 & 82 & 2.7 & 4.8 \\
\hline
\end{tabular}

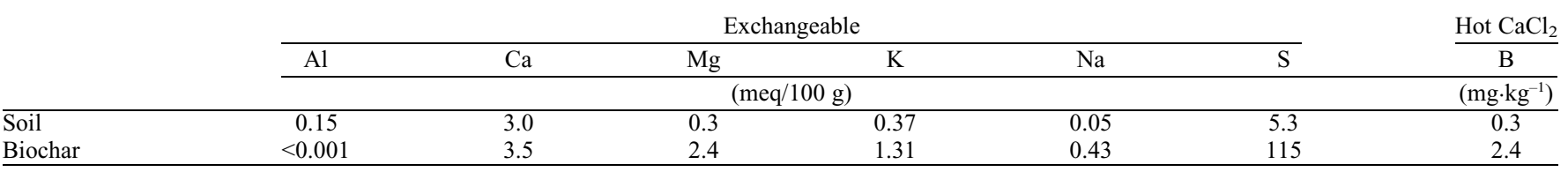

$\mathrm{DTPA}=$ diethylenetriaminepentaacetic acid $\mathrm{C}=$ carbon; $\mathrm{P}=$ phosphorus; $\mathrm{K}=$ potassium $; \mathrm{Cu}=$ copper; $\mathrm{Fe}=$ iron; $\mathrm{Mn}=$ manganese $\mathrm{Zn}=$ zinc; $\mathrm{Al}=$ aluminum $;$ $\mathrm{Ca}=$ calcium; $\mathrm{Mg}=$ magnesium; $\mathrm{Na}=$ sodium; $\mathrm{S}=$ sulfur; $\mathrm{B}=$ boron. 
solution ratio after $1 \mathrm{~h}$ mixing using a combination $\mathrm{pH}$ electrode (Rayment and Higginson, 1992). Soil total C was measured using the Walkley and Black (1932) method. Total $\mathrm{C}$ of biochar was measured using a $\mathrm{CHN} / \mathrm{O}$ analyzer (PerkinElmer, Waltham, MA). Total $\mathrm{NH}_{4}{ }^{+}$and $\mathrm{NO}_{3}{ }^{-}$were measured using a Lachat Flow Injection Analyser (Searle et al., 1984). Extractable S was measured using $\mathrm{KCl}$ extraction (Blair et al., 1991). Available P and K were measured using the Colwell (1995) method. Available $\mathrm{Cu}, \mathrm{Fe}, \mathrm{Mn}$, and $\mathrm{Zn}$ were measured using diethylenetriaminepentaacetic acid extraction (Rayment and Higginson, 1992). Exchangeable cations ( $\mathrm{Al}, \mathrm{Ca}, \mathrm{Mg}, \mathrm{K}$, and $\mathrm{Na}$ ) were measured using $0.1 \mathrm{M} \mathrm{BaCl} / 0.1 \mathrm{M}$ $\mathrm{NH}_{4} \mathrm{Cl}$ extraction according to the Gillman and Sumpter (1986) method. Available B was measured by extraction with boiling $\mathrm{CaCl}_{2}$ (Rayment and Higginson, 1992).

Plant nutrient concentration was analyzed for selected treatments with three analytical replicates used for each treatment. Leaves from the entire plant were used for nutrient analysis to obtain the minimum amount required for analysis. Dried plant leaves were finely ground. $\mathrm{N}$ analysis of leaf material was according to the procedure of Sweeny and Rexroad (1987). Leaf material was combusted at $950{ }^{\circ} \mathrm{C}$ in oxygen using a Leco FP-428 N Analyser (LECO Australia Pty Ltd, Castle Hill, Australia). The released N from the sample was measured as it passed through a thermal conductivity cell. For analysis of $\mathrm{P}$, $\mathrm{K}, \mathrm{Ca}, \mathrm{Mg}, \mathrm{S}, \mathrm{Fe}, \mathrm{Cu}, \mathrm{Mn}, \mathrm{Zn}, \mathrm{B}$, and $\mathrm{Na}$, the procedure of McQuaker et al. (1979) was used. Leaf material was digested in nitric acid using a Milestone microwave oven and nutrients were measured by inductively coupled plasma atomic emission spectroscopy. For the analysis of $\mathrm{Cl}^{-}$and $\mathrm{NO}_{3}{ }^{-}$in leaves, the procedure of Zall et al. (1956) was used. Leaf material was extracted in deionized water and the $\mathrm{Cl}^{-}$and $\mathrm{NO}_{3}{ }^{-}$were measured simultaneously using a Lachat Flow Injection Analyser (Lachat Instruments, Loveland, CO). The nitrate was reduced to nitrite through a copperized cadmium column and the nitrite measured colorimetrically at $520 \mathrm{~nm}$. The concentration of chloride was measured colorimetrically at $480 \mathrm{~nm}$.

Experimental design and data analysis. A randomized block design of seven blocks was used for the pot trials. The autoclaved soil treatment was contained in a separate block to reduce microbial contamination from neighboring treatments. Within the autoclaved treatments, individual rootstock position was randomized.

All data were analyzed using SPSS software (SPSS Inc., Chicago, IL). Univariate analysis was performed using least significant difference to compare the main effects of biochar, the root medium treatments, and their interaction. All significant differences were assessed at a significance level of $(P<0.05)$ with least significant differences calculated using Fisher's protected method.

High variability was found in rootstock growth with rootstocks breaking dormancy over a period of $70 \mathrm{~d}$ from first to last. Plant growth, leaf symptoms, and nutrient concentrations were also highly variable. Potential confounding sources of rootstock variability were investigated. It was found that biochar had no significant effect on root medium temperature. Root medium temperature, rootstock weight, and spatial variability (block effect) had no significant effect on rootstock growth. Hence, no confounding sources of variability were identified. To reduce the effects of rootstock variability, those that had not achieved greater than $5 \mathrm{~cm}$ shoot growth by the time of first measurement $(14 \%)$ and those that died during the course of the trial $(3 \%)$ were excluded from all analyses.

\section{Results}

Impacts of biochar on soil pH. No significant growth response was found for either lime or biochar alone (results not shown). Biochar raised $\mathrm{pHc}$ from $4.68 \pm 0.09$ to $4.86 \pm 0.08(P=$ $0.017)$, whereas lime raised $\mathrm{pHc}$ levels from $4.68 \pm 0.09$ to $7.03 \pm 0.04(P<0.0005)$.

Impacts of addition of autoclaved soil on biological activity. No significant difference in SIR was found between soil with and without biochar addition.

A significant interaction between biochar addition and autoclaved soil occurred with autoclave treatments significantly reducing rootstock total dry mass for the soil and sand without biochar by $34 \%$ and increasing it $34 \%$ with biochar compared with unaltered media (Fig. 1). For the autoclave-treated soil, addition of biochar was associated with an increase in rootstock total dry mass of $102 \%$.

Fertilization effects of biochar. Biochar addition to sand was associated with a significant increase in rootstock total dry mass for every fertilization treatment: an increase that was not detected for sand alone. The Total -PKCa treatment increased total dry mass by $75 \%$, the NPKCa Fert treatment increased it by $141 \%$, whereas the Total Fert treatment increased growth by $220 \%$ (Fig. 2).

The Total $-\mathrm{PKCa}$ treatments resulted in leaf scorch, which was most severe for the non-biochar-treated pots (Figs. 3A and 4A). Both NPKCa Fert treatments developed misshaped and small young leaves (Figs. 3C-D and 4B). In no biochar NPKCa Fert treatments, misshapen leaves tended to be more severe and were associated with reduced

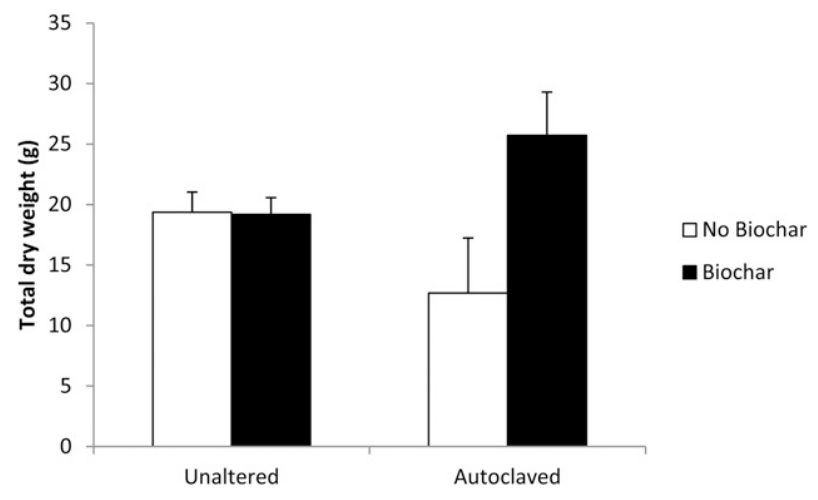

Fig. 1. Mean total dry weight of apple rootstocks. Least significant difference $=5.3$. Individual sem used for error bars. Rootstocks were grown in a soil plus $50 \mathrm{t} \cdot \mathrm{ha}^{-1}$ (equivalent) biochar substrate ("Biochar") or a control soil only substrate ("No Biochar") each subjected to two pre-treatments: 1) unaltered soil; and 2) autoclaved soil.

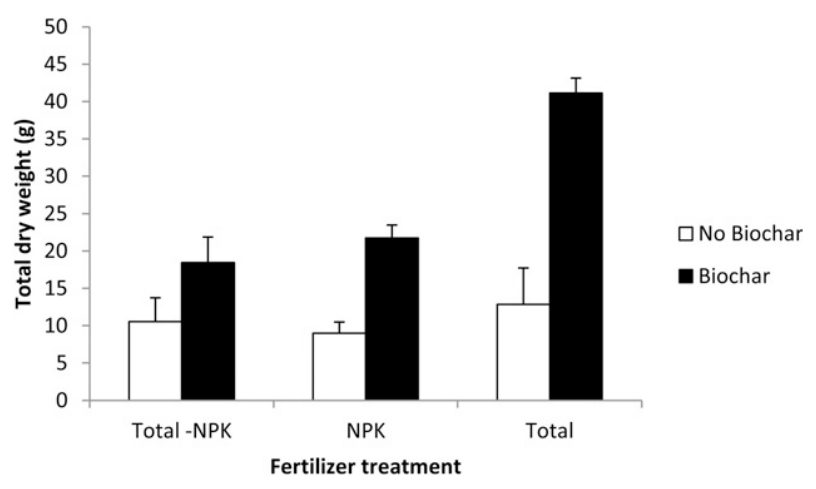

Fig. 2. Mean total dry weight of apple rootstock growth. Rootstocks were grown in a sand and $50 \mathrm{t} \cdot \mathrm{ha}^{-1}$ (equivalent) biochar substrate (Biochar) or a control sand-only substrate (No Biochar) each receiving three different fertilization regimes: 1) all essential plant nutrients except nitrogen $(\mathrm{N})$, phosphorus $(\mathrm{P})$, potassium (K) (Total-NPK); 2) N, P, K only (NPK); or 3) a total nutrient fertilization regime (Total). Least significant difference $=2.1$. Individual SEM used for error bars. Biochar $\times$ fertilizer interaction $\left(\mathrm{F}_{2,36}: 6.1 ; P=0.005\right)$. 

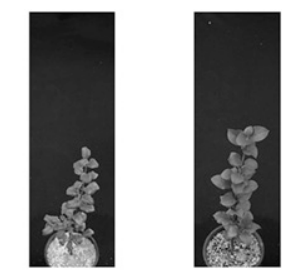

a

No Biochar

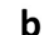

Total - PKCa

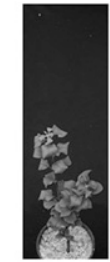

c

No Biochar NPKC

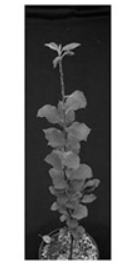

d

Biochar

Fig. 3. Examples of rootstocks from each treatment. Rootstocks were grown in a sand and $50 \mathrm{t} \cdot \mathrm{ha}^{-1}$ (equivalent) biochar substrate or a control sand only substrate each receiving three different fertilization regimes: 1) all essential plant nutrients except phosphorus (P), potassium (K), and calcium $(\mathrm{Ca})$ (Total-PKCa); 2) N, P, K, and Ca only (NPKCa); or 3) a total nutrient fertilization regime (Total).

stem elongation, purple veins, and severe interveinal chlorosis of young leaves (Figs. $3 \mathrm{C}$ and $4 \mathrm{C}$ ). The visual symptoms and growth differences were largest for the Total Fert treatments: Total Fert non-biochar-treated plants were severely stunted and leaves developed interveinal chlorosis with much smaller leaves and narrower stems (Fig. $3 \mathrm{E})$, whereas for Total Fert biochar treatments leaves, were dark green and healthy (Figs. 3F and 4D).

The addition of biochar was associated with significant increases in leaf concentrations of $\mathrm{Ca}, \mathrm{B}$, and $\mathrm{S}$ for all treatments (Table 3). A significant biochar $\times$ fertilizer interaction was found for leaf concentration of $\mathrm{K}$. Biochar increased concentrations of $\mathrm{K}$ in leaves for NPKCa Fert treatment, had no significant effect on $\mathrm{K}$ concentrations for the Total-PKCa treatment, and $\mathrm{K}$ concentrations were reduced in the Total-Fertilizer treatment. There was a significant interaction effect for biochar $\times$ fertilizer for leaf $\mathrm{Fe}$ concentration. Fe concentrations significantly decreased for Total -PKCa and Total Fert treatments but significantly increased for NPKCa Fert treatment. For all other plant nutrients, no significant effect of biochar was found.

Effects of biochar application rate. Biochar had no significant effect on rootstock growth at any application level in any fertilization treatment. However, addition of biochar was associated with a significant increase in leaf concentration of B from 24 to $28 \mathrm{mg} \cdot \mathrm{kg}^{-1}(P=0.036)$ and a significant decrease in Fe from 122 to $95 \mathrm{mg} \cdot \mathrm{kg}^{-1}(P=$ $0.048)$. A biochar $\times$ fertilizer interaction was found for Mn concentrations with biochar associated with a significant decrease in $\mathrm{Mn}$ for both $\mathrm{N}$ fertilizer treatments (from 111 to $76 \mathrm{mg} \cdot \mathrm{kg}^{-1}$ ) and the Total Fert treatments (from 162 to $107 \mathrm{mg} \cdot \mathrm{kg}^{-1}$ ), whereas no significant difference was found for the No Fert treatment $(P=0.041)$.

\section{Discussion}

Impacts of biochar on soil pH. Optimal soil $\mathrm{pH}$ for apples is between 6.5 and 7 but in this trial, biochar only increased soil $\mathrm{pH}$ from 4.7 to 4.9. This contrasts with an increase of
$\mathrm{pH}$ from 6.3 to 7.1 as a result of the equivalent of $6 \mathrm{tC} /$ ha biochar to soils cropped for 5 years reported by Kimetu et al. (2008). The discrepancy may be explained by a combination of differences between the makeup of the green waste-based biochar we used and its low $\mathrm{pH}$. Inherent differences occur as a result of materials used and pyrolysis processes and the biochar used in this study had $\mathrm{pH}$ of only 6.4 relative to $\mathrm{pH} 9.4$ used by Kimetu et al. (2008). Yuan and Xu (2011) report that the soil liming effect of biochar addition was strongly correlated $\left(R^{2}=0.95\right)$ with $\mathrm{pH}$ of the biochar used for amendment. Our findings are consistent with this. In contradiction to Hypothesis 1, biochar did nonsignificantly increase growth of apple rootstocks through improved soil $\mathrm{pH}$. However, nor did the addition of lime, which increased soil $\mathrm{pHc}$ from 4.7 to 7.0 .

Impacts of autoclaving on biological activity. In contradiction to Hypothesis 2, SIR measurements indicate that biochar did not increase plant growth through increased microbial activity and associated nutrient mineralization. This conflicts with findings of Steiner et al. (2008) in which a linear relationship between microbial population growth and biochar addition was found. However, biochar significantly interacted with autoclaved soil to increase plant growth. This may be the result of the increased availability of $\mathrm{N}$ and $\mathrm{P}$ mineralized as a result of autoclaving (Chambers and Attiwill, 1994). However, the observation of reduced growth in autoclaved treatment without biochar is not consistent with this interpretation.

Fertilization effects of biochar. Biochar addition to sand was associated with increased $\mathrm{B}, \mathrm{Ca}$, and $\mathrm{S}$ availability. This is consistent with Hypothesis 3, that biochar can increase plant growth through fertilization with non-volatile nutrients. According to Peryea et al. (2003), the concentration of B was deficient in the leaves of all the non-biochar treatments and they are deficient or bordering on deficient in $\mathrm{Ca}$ and $\mathrm{S}$. We found significant increases, relative to controls, in nutrient uptake for all essential plant nutrients in the biochar treatments. The biochar contained significant levels of extractable $\mathrm{Ca}, \mathrm{S}, \mathrm{B}, \mathrm{P}, \mathrm{K}, \mathrm{Fe}, \mathrm{Zn}$, and $\mathrm{Cu}$, suggesting that plant uptake of these nutrients was increased by biochar addition and contributed to the observed plant growth response.

Consistent with the leaf nutrient analyses, the plants of the NPKCa Fert treatments without biochar addition displayed purpling of veins, stunted shoot growth, and stunting and interveinal chlorosis of the youngest leaves, which are symptoms of B and $\mathrm{Zn}$ deficiency in apples. In Total Fert treatments, without biochar, chlorosis of young leaves progressed into older leaves over time, which is consistent with S deficiency. Leaf scorch seen in the $\mathrm{N}-\mathrm{Mg}-\mathrm{S}$ treatments is a classic symptom of $\mathrm{K}$ deficiency. These symptoms disappeared or were substantially reduced with biochar additions indicating that biochar is increasing $\mathrm{K}, \mathrm{S}, \mathrm{B}$, and $\mathrm{Zn}$ availability in the root medium.

The increased uptake of $S$ found in this trial has not been reported in previous biochar studies. This is likely to be the result of the high $\mathrm{S}$ in the biochar given that the pyrolysis temperature $\left(350{ }^{\circ} \mathrm{C}\right)$ used to produce the biochar was low in comparison with that used in most other studies (Joseph et al., 2010). Above $375^{\circ} \mathrm{C}$, volatilization of $\mathrm{S}$ is known to occur (Neary et al., 1999). Also leaf biochars are higher in $\mathrm{S}$ than bark or wood biochars (Abdullah et al., 2010). Hence, the green waste biochar used could be expected to have higher S than wood-based biochars on which the majority of research has been done (Sohi et al., 2010).

The fertilizer $\times$ biochar interaction may give some indication of the relative importance of fertilization resulting from biochar on plant growth. The largest growth response to biochar was in the Total Fert treatment, despite being provided with all essential plant nutrients. For the Total Fert no biochar treatment, the leaves developed severe nutrient deficiency symptoms and grew very poorly. The poor growth for the no biochar treatment could be explained by nutrient leaching, because sand has a very low CEC and anion exchange capacity. Biochar could have reduced nutrient deficiency and increased plant growth through acting as a slow-release fertilizer and/or by reducing nutrient leaching. Reduced leaching resulting from biochar application could be expected to have a greater effect where all nutrients are provided in fertilizer, e.g., Total Fert treatment, and this is what was found. However, we emphasize that these are tacit results because the impact of biochar on leaching was not directly investigated in this study.

Effects of biochar application rate. Despite large growth responses found where biochar was incorporated into the sand medium, no significant growth response to biochar amendment was found in soil for any combination of biochar application level or fertilization treatment in this trial. This is likely to be partly the result of the much higher nutrient content of the soil as well as greater nutrient retention; hence, potential improvements in these properties from biochar would have less effect. For instance, 

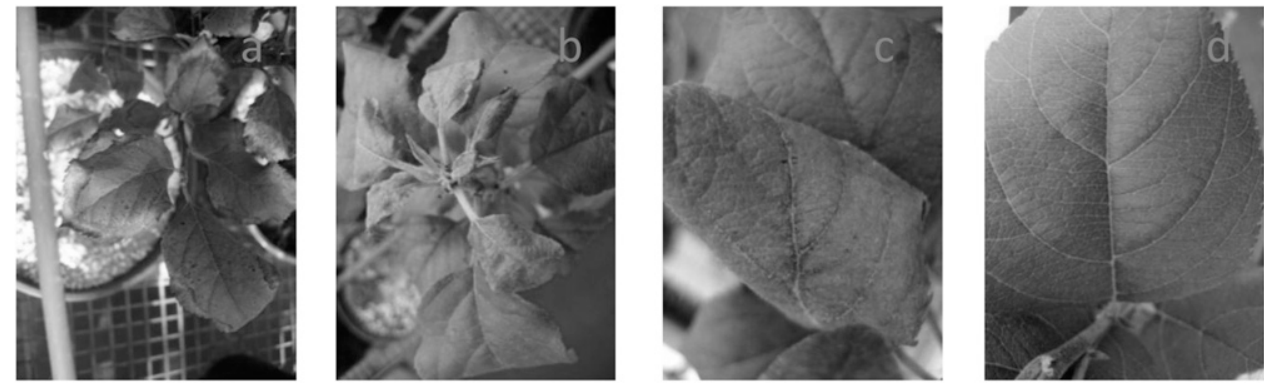

Fig. 4. Example pictures of visual deficiency/toxicity symptoms: (A) severe leaf scorch (Total-PKCa Fert.-biochar), (B) shoot stunting and undersized young leaves (NPKCa-biochar), (C) purple veins, interveinal chlorosis and leaf curling (NPKCa Fert--biochar), and (D) healthy leaf (Total Fert. + biochar).

Table 3. Leaf nutrient concentrations for sand treatments. ${ }^{\mathrm{z}}$

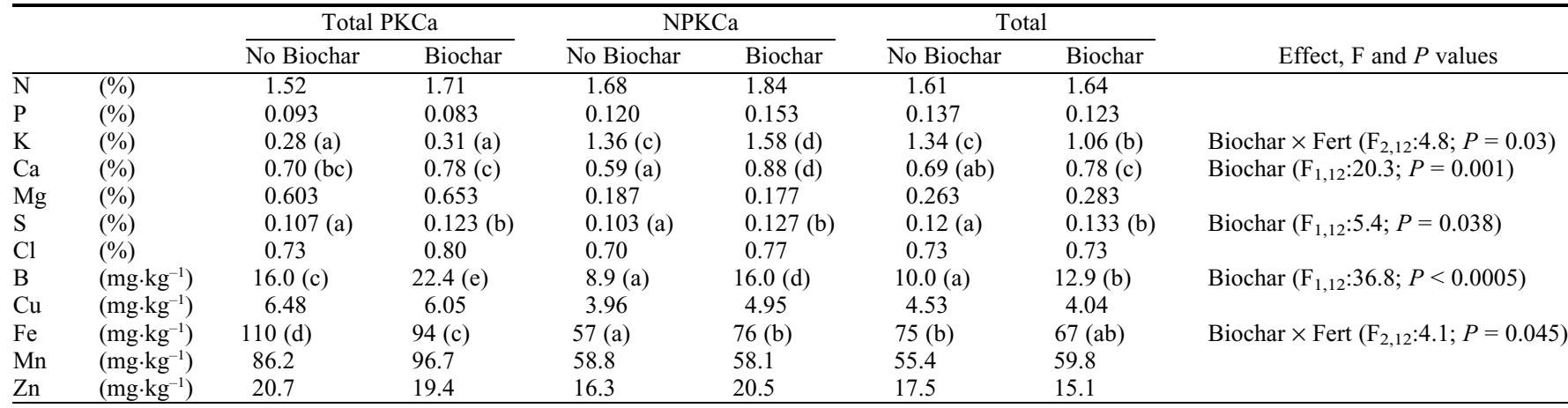

${ }^{\mathrm{z}}$ Different letters denote significant differences between treatment means.

$\mathrm{N}=$ nitrogen; $\mathrm{P}=$ phosphorus; $\mathrm{K}=$ potassium; $\mathrm{Ca}=$ calcium; $\mathrm{Mg}=$ Magnesium; $\mathrm{S}=$ sulfur $\mathrm{Cl}=\mathrm{Chlorine} ; \mathrm{B}=\mathrm{Boron} ; \mathrm{Cu}=\mathrm{Copper} ; \mathrm{Fe}=\mathrm{Iron} ; \mathrm{Mn}=\mathrm{Manganese}$; $\mathrm{Zn}=$ Zinc.

biochar addition increased foliar concentrations of B in leaves for rootstocks in soil as it did in sand. However, although for sand many treatments produced concentrations in leaves below deficiency levels, for soil, all treatments supported plant B concentrations in the normal range and hence no growth response was observed. The fact that a significant growth response was not found in soil is at odds with other research that has found positive growth responses to biochar in similar $\mathrm{C}$ and nutrient-poor, acidic soils (e.g., Chan et al., 2007; Kimetu et al., 2008; Rondon et al., 2007). This may be the result of the high sand content of the soil in this trial as well as the use of perlite added to reduce hard setting and increase drainage. However, it should be noted that Chan et al. (2007) found decreases in biomass production at moderate, in contrast to high, rates in a hard setting soil that benefitted from the structural advantages of incorporated biochar. Additionally, the lack of a liming effect in the current study may be the result of the inherently low $\mathrm{pH}$ of biochar relative to that used by Chan et al. (2007; $\mathrm{pH} \mathrm{CaCl}_{2}$ 9.4), Kimetu et al. (2008; $\mathrm{pH} \mathrm{CaCl}{ }_{2}$ 9.4), or Rondon et al. (2007; pH water 7.00).

This study has shown that application of biochar to the growth media of apple rootstocks can significantly affect plant growth and nutrition. It appears likely that fertilization with nutrients contained within biochar was the major source of $\mathrm{Ca}, \mathrm{S}$, and $\mathrm{B}$ and possibly $\mathrm{K}$ and $\mathrm{Zn}$. In interpreting these results, it needs to be noted that the fertilizer properties of biochar will inevitably decline, whereas CEC of biochar increases over time (Cheng et al., 2006, 2008; Liang et al., 2006) and longer-term studies are warranted for investigation of effects on perennial crops. Although the effect of biochar in the soil may change over time, this research demonstrates biochar can have positive effects on plant nutrition and growth in the short term.

\section{Literature Cited}

Abdullah, H., K.A. Mediaswanti, and H.W. Wu. 2010. Biochar as a fuel: 2. Significant differences in fuel quality and ash properties of biochars from various biomass components of mallee trees. Energy Fuels 24:19721979.

Anderson, J.P.E. and K.H. Domsch. 1978. A physiological method for the quantitative measurement of microbial biomass in soils. Soil Biology and Biochemistry 10:215-221.

Blair, G., N. Chinoim, R. Lefroy, G. Anderson, and G. Crocker. 1991. A soil sulfur test for pastures and crops. Austral. J. Soil Res. 29:619-626.

Chambers, D.P. and P.M. Attiwill. 1994. The ashbed effect in Eucalyptus regnans forestChemical, physical and microbiological changes in soil after heating or partial sterilization. Austral. J. Bot. 42:739-749.

Chan, K.Y., L. Van Zwieten, I. Meszaros, A Downie, and S. Joseph. 2007. Agronomic values of greenwaste biochar as a soil amendment. Austral. J. Soil Res. 45:629-634.

Chan, K.Y., L. Van Zwieten, I. Meszaros, A. Downie, and S. Joseph. 2008. Using poultry litter biochars as soil amendments. Austral. J. Soil Res. 46:437-444.
Chan, K.Y. and Z. Xu. 2009. Biochar: Nutrient properties and their enhancement, p. 67-84. In: Lehmann, J. and S. Joseph (eds.). Biochar for environmental management: Science and technology. Earthscan, London, UK.

Chatterjee, A., R. Lal, L. Wielopolski, M.Z. Martin, and M.H. Ebinger. 2009. Evaluation of different soil carbon determination methods. Crit. Rev. Plant Sci. 28:164-178.

Cheng, C.H., J. Lehmann, and M.H. Engelhard. 2008. Natural oxidation of black carbon in soils: Changes in molecular form and surface charge along a climosequence. Geochim. Cosmochim. Acta 72:1598-1610.

Cheng, C.H., J. Lehmann, J.E. Thies, S.D. Burton, and M.H. Engelhard. 2006. Oxidation of black carbon by biotic and abiotic processes. Org. Geochem. 37:1477-1488.

Colwell, J. 1995. Chemical analysis, p. 64. In: Rayment, G. and F. Gigginson (eds.). Australian laboratory handbook of soil and chemical methods. Inkata Press, Melbourne, Australia.

Dalling, J.W., K. Winter, K.M. Andersen, and B.L. Turner. 2013. Artefacts of the pot environment on soil nutrient availability: Implications for the interpretation of ecological studies. Plant Ecol. 214:329-338.

Deluca, T., M.D. MacKenzie, and M.J. Gundale. 2009. Biochar effects on soil nutrient transformations, p. 251-270. In: Lehmann, J. and S. Joseph (eds.). Biochar for environmental management: Science and technology. Earthscan, London, UK.

Gillman, G.P. and E.A. Sumpter. 1986. Modification to the compulsive exchange method for measuring exchange characteristics of soils. Austral. J. Soil Res. 24:61-66.

Hoagland, D. and D. Arnon. 1950. The waterculture method for growing plants without soil. University of California Agricultural Experiment Station, Berkeley, CA. 
Joseph, S.D., M. Camps-Arbestain, Y. Lin, P. Munroe, C.H. Chhia, J. Hook, L. van Zweiten, S. Kimber, A. Cowie, B.P. Singh, J. Lehmann, N. Foidl, R.J. Smernik, and J.E. Amonette. 2010. An investigation into the reactions of biochar in soil. Austral. J. Soil Res. 48:501-515.

Keiluweit, M. and M. Kleber. 2009. Molecularlevel interactions in soils and sediments: The role of aromatic p-systems. Environ. Sci. Technol. 43:3421-3429.

Kimetu, J.M., J. Lehmann, S.O. Ngoze, D.N. Mugendi, J.M. Kinyangi, S. Riha, L. Verchot, J.W. Recha, and A.N. Pell. 2008. Reversibility of soil productivity decline with organic matter of differing quality along a degradation gradient. Ecosystems (N.Y.) 11:726-739.

Kuzyakov, Y., I. Subbotina, H.Q. Chen, I. Bogomolova, and X.L. Xu. 2009. Black carbon decomposition and incorporation into soil microbial biomass estimated by $\mathrm{C}-14$ labeling. Soil Biol. Biochem. 41:210-219.

Lehmann, J., J.P. da Silva, C. Steiner, T. Nehls, W. Zech, and B. Glaser. 2003. Nutrient availability and leaching in an archaeological Anthrosol and a Ferralsol of the Central Amazon basin: Fertilizer, manure and charcoal amendments. Plant Soil 249:343-357.

Liang, B., J. Lehmann, D. Solomon, J. Kinyangi, J. Grossman, B. O’Neill, J.O. Skjemstad, J. Thies, F.J. Luizao, J. Petersen, and E.G. Neves. 2006. Black carbon increases cation exchange capacity in soils. Soil Sci. Soc. Amer. J 70:1719-1730.
McIntyre, D.S. and J.L. Loveday. 1974. Particle size analysis, p. 88-100. In: Loveday, J.L. (ed.). Method for analysis of irrigated soils. Commonwealth Bureau of Soils, Buckingham, UK.

McQuaker, N.R., D.F. Brown, and P.D. Kluckner. 1979. Digestion of environmental materials for analysis by inductively coupled plasmaatomic emission spectrometry. Anal. Chem. 51:1082-1084.

Neary, D.G., C.C. Klopatek, L.F. DeBano, and P.F. Ffolliott. 1999. Fire effects on belowground sustainability: A review and synthesis. For. Ecol. Mgt. 122:51-71.

Peryea, F.J., D. Neilsen, and G. Neilsen. 2003. Boron maintenance sprays for apple: Earlyseason applications and tank-mixing with calcium chloride. HortScience 38:542.

Rayment, G. and F. Higginson. 1992. Australian laboratory handbook of soil and water chemical methods. Inkata Press, Melbourne, Australia.

Rondon, M.A., J. Lehmann, J. Ramirez, and M. Hurtado. 2007. Biological nitrogen fixation by common beans (Phaseolus vulgaris L.) increases with bio-char additions. Biol. Fertil. Soils 43:699-708.

Rutto, K.L. and F. Mizutani. 2006. Effect of mycorrhizal inoculation and activated charcoal on growth and nutrition in peach (Prunus persica Batsch) seedlings treated with peach root-bark extracts. J. Jpn. Soc. Hort. Sci. 75:463-468
Searle, E., M.W. Cass, A.J. Phipps, and C.M. Thompson. 1984. Analysis of used lubricating oils for diesel fuel dilution by multi-dimensional gas-chromatography. Analyst (Lond.) 109:1223-1224.

Sohi, S.P., E. Krull, E. Lopez-Capel, and R. Bol. 2010. A review of biochar and its use and function in soil. Adv. Agron. 105:47-82.

Steiner, C., K.C. Das, M. Garcia, B. Forster, and W. Zech. 2008. Charcoal and smoke extract stimulate the soil microbial community in a highly weathered xanthic Ferralsol. Pedobiologia (Jena) 51:359-366.

Sweeny, R. and P. Rexroad. 1987. Comparison of LECO FP-228 'Nitrogen Determinator' with AOAC copper catalyst Kjeldahl method for crude protein. J. Assoc. Off. Anal. Chem. 70:1028-1030.

Wagai, R., L.M. Mayer, and K. Kitayama. 2009. Nature of the 'occluded' low-density fraction in soil organic matter studies: A critical review. Soil Sci. Plant Nutr. 55:13-25.

Walkley, A. and I. Black. 1932. An examination of the Degtjareff method for determining soil organic matter and a proposed modification of the chromic acid titration method. Soil Sci. 37:29-38.

Yuan, J.-H. and R.-K. Xu. 2011. The amelioration effects of low temperature biochar generated from nine crop residues on an acidic Ultisol. Soil Use Mgt. 27:110-115.

Zall, D.M., D. Fisher, and M.Q. Garner. 1956. Photometric determination of chlorides in water. Anal. Chem. 28:1665-1668. 